\title{
Partisipasi Masyarakat dalam Pengembangan Kawasan Agropolitan Program Padat Karya Tunai di Desa Tasikmadu Kecamatan Palang Kabupaten Tuban \\ (Community Participation in Development of Agropolitan Area Cash for Works Program in Tasikmadu Village, Palang District, Tuban District)

\author{
Winda Ayuning Lestari ${ }^{1}$, Eny Lestari ${ }^{2}$, Eksa Rusdiyana ${ }^{3)}$
}

Program Studi Penyuluhan dan Komunikasi Pertanian Fakultas Pertanian Universitas Sebelas Maret

Jl. Ir. Sutami No. 36 A Kentingan Surakarta 57126 Telp/Fax (0271) 637457

Email : windaayuninglestari@gmail.com

\begin{abstract}
This research aims to analyze the level of community participation in the development of the agropolitan area Cash for Works Program, analyzing internal factors and external factors that influence community participation; and analyze the relationship between internal factors and external factors of participation with the level of community participation in the development of the agropolitan area Cash for Works Program in Tasikmadu Village, Palang District, Tuban Regency. This study uses quantitative methods with survey techniques. The research location is in Tasikmadu Village, Palang District, Tuban Regency because there is an agropolitan area of star fruit plantation. The sampling technique by multistage cluster random sampling was 69 respondents. Data analysis using Spearman Rank correlation test. The results of the study showed: (1) Age of the community included in the category of age 36-55 years, with an average level of education graduating from high school / equivalent, land ownership area $\leq 0.3 \mathrm{ha}$, income level of the agricultural sector $>2.1$ million, length live on average $>21$ years, with the level of cosmopolitan including very low category and stakeholders including quite active category. (2) The level of community participation is included in the category of moderate participation and is on the consultation ladder. (3) Spearman's Rank correlation test shows that internal and external factors that are significantly related to community participation are the extent of land ownership, income level and the level of cosmopolitan, while age, education level, length of stay, and stakeholders are not significantly related.
\end{abstract}

Keywords: Agropolitan Area, Cash for Works Program, Participation.,Starfruit.

\begin{abstract}
Abstrak: Penelitian ini bertujuan untuk menganalisis tingkat partisipasi masyarakat dalam pengembangan kawasan agropolitan Program Padat Karya Tunai, menganalisis faktor internal dan faktor eksternal yang mempengaruhi partisipasi masyarakat; dan menganalisis hubungan antara faktor internal dan faktor eksternal partisipasi dengan tingkat partisipasi masyarakat dalam pengembangan kawasan agropolitan Program Padat Karya Tunai di Desa Tasikmadu Kecamatan Palang Kabupaten Tuban. Penelitian ini menggunakan metode kuantitatif dengan teknik survei. Lokasi penelitian di Desa Tasikmadu Kecamatan Palang Kabupaten Tuban karena terdapat kawasan agropolitan kebun belimbing. Teknik pengambilan sampel secara multistage cluster random sampling sebanyak 69 responden.Analisis data menggunakan uji korelasiRank Spearman. Hasil penelitian menunjukkan:(1) Umur masyarakat termasuk dalam kategori umur 36-55 tahun, dengan rata-rata tingkat pendidikannya tamat SLTA/ Sederajat, luas kepemilikan lahan $\leq 0,3 \mathrm{Ha}$, tingkat pendapatan sektor usaha tani $>2,1$ juta, lamanya tinggal rata-rata $>21$ tahun, dengan tingkat kekosmopolitan termasuk kategori sangat rendah dan stakeholder termasuk kategori cukup aktif. (2) Tingkat partisipasi masyarakat termasuk dalam kategori partisipasi sedang dan berada pada tangga konsultasi. (3) Uji korelasi Rank Spearman menunjukkan bahwa faktor internal dan faktor eksternal yangberhubungan signifikan terhadappartisipasi masyarakat yaitu luas kepemilikan lahan, tingkat pendapatan dan tingkat kekosmopolitan, sedangkan umur, tingkat pendidikan, lamanya tinggal, dan stakeholder tidak berhubungan secara signifikan.
\end{abstract}

Kata Kunci: Belimbing, Kawasan Agropolitan, Padat Karya Tunai, Partisipasi. 


\section{PENDAHULUAN}

Pembangunan nasional merupakan upaya untuk mewujudkan tujuan masyarakat yakni kesejahteraan yang adil dan makmur. Kegiatan tersebut tidak lepas dari peran serta kerjasama antara pemerintah pusat dan pemerintah daerah dalam menentukan kebijakan terkait (Azzumar, 2011).Fokus pembangunan Jawa Timur tahun 2014-2019 diarahkan pada pemantapan perkotaan Pusat Kegiatan Nasional sebagai metropolitan dan pengembangan Pusat Kegiatan Wilayah sebagai pusat agrobisnis yang difokuskan pada pengembangan kawasan strategis, utamanya kawasan agropolitan, kawasan agroindustri, kawasan metropolitan dan kawasan tertinggal. Kabupaten Tuban adalah salah satu kawasan motor pertumbuhan yang berada pada wilayah administratif Provinsi Jawa Timur. Luas wilayah Kabupaten Tuban mencapai 1.834,15 $\mathrm{km}^{2}$. Menurut BPS (2017), Kecamatan Palang memiliki potensi di bidang pertanian dan perikanan. Komoditi utama di bidang pertanian sub hortikultura yaitu belimbing. Penghasil belimbing terbesar di Kecamatan Palang adalah Desa Tasikmadu.

Salah satu kebijakan pemerintah dalam pembangunan adalah Program Padat Karya Tunai. Program ini merupakan kegiatan pemberdayaan masyarakat marginal/ miskin yang bersifat produktif berdasarkan pemanfaatan sumber daya alam, tenaga kerja dan teknologi lokal dalam rangka mengurangi kemiskinandan meningkatkan pendapatan. Padat Karya Tunai adalahskema baru dalam pengalokasian dana desa. Prioritasnya untuk pembangunan sarana prasarana dan pemberdayaan masyarakat (Kementerian PPN/ Bappenas, 2018).Pelaksanaan Program Padat Karya Tunai di Desa Tasikmadu Kecamatan Palang Kabupaten Tuban dilakukan melalui pengembangan kawasan agropolitan.

Pengembangan kawasan agropolitan

melalui Program Padat Karya Tunai tidak terlepas dari partisipasi masyarakat.
Partisipasi diperlukan saat pembangunan karena masyarakat yang akan menikmati hasil pembangunan (Wibowo, 2016). Dewasa ini pengembangan kawasan agropolitan kebun belimbing dianggap stagnan. Terdapat beberapa jenis kegiatan program yang menjadikan fokus masyarakat terbagi untuk mengikuti setiap kegiatan, dan adanya keberagaman sosial ekonomi masyarakat. Kondisi tersebut memunculkan tanggapan yang berbeda mengenai adanya alternatif solusi yang ditawarkan dalam menghadapi permasalahan dalam berpartisipasi. Tujuan dari penelitian ini adalah untuk menganalisis faktor internal dan faktor eksternal yang mempengaruhi partisipasi masyarakat dalam pengembangan kawasan agropolitan Program Padat Karya Tunai, menganalisis tingkat partisipasi masyarakat dalam pengembangan kawasan agropolitan Program Padat Karya Tunai, dan menganalisis hubungan antara faktor internal dan faktor eksternal terhadap tingkat partisipasi masyarakat dalam pengembangan kawasan agropolitan Program Padat Karya Tunai di Desa Tasikmadu Kecamatan Palang Kabupaten Tuban.

\section{METODE PENELITIAN}

Metode dasar yang digunakan adalah kuantitatif dengan teknik survei. Penentuan lokasi dilakukan secara sengaja di Desa Tasikmadu Kecamatan Palang Kabupaten Tuban dengan pertimbangan Desa Tasikmadu sebagai sentra kawasan agropolitan kebun belimbing dan partisipan Program Padat Karya Tunai. Penarikan sampel dilakukan dengan multistage cluster random samplingsejumlah 69 orang.Jenis data yang digunakan adalah data kuantitatif dan kualitatif, serta sumber data yaitu sumber data primer dan sekunder yang diambil dengan cara wawancara, kuesioner, observasi dan pencatatan. Penelitian ini menggunakan uji validitas dan reliabilitas untuk menguji kuesioner. Uji validitas menggunakan korelasi pearson dengan $r$ tabel 0,306 yang dibandingkan dengan $r$ hitung. Hasil analisis uji validitas terdapat 17 item pertanyaan faktor internal dan faktor eksternal serta 52 item 
pertanyaan partisipasi masyarakat dinyatakan valid. Berdasarkan uji reliabilitas kuesioner diperoleh nilai conbach's alpha sebesar 0,825 yang berarti nilai tersebut lebih dari 0,600 sehingga kuesioner dikatakan memiliki reliabilitas yang baik. Analisis data pada penelitian ini guna untuk menguji hubungan antara faktor internal dan faktor eksternal dengan partisipasi masyarakat menggunakan korelasi Rank Spearman $\left(r_{s}\right)$ dan uji $\mathrm{t}$ untuk menguji tingkat signifikansinya.

\section{HASIL DAN PEMBAHASAN}

\section{Keadaan Umum Lokasi Penelitian}

Desa Tasikmadu adalah satu desa di Kecamatan Palang Kabupaten Tuban. Desa Tasikmadu memiliki luas wilayah $254 \mathrm{Ha}$ dengan luas lahan sawah $29 \mathrm{Ha}$ dan luas lahan kering 103 Ha. Tingkat pendidikan penduduk di Desa Tasikmadu sebagian besar adalah SLTA/sederajat yaitu sebesar 1.641 orang. Komoditas pertanian terbesar di Desa Tasikmadu adalah jagung dengan hasil panen mencapai 1.067 Ton sedangkan komoditas hortikutura unggulan adalah belimbing hingga 510 Ton.

\section{Pengembangan Kawasan Agropolitan Program Padat Karya Tunai}

Salah satu kebijakan pemerintah dalam pembangunan adalah Program Padat Karya Tunai. Maksud dan tujuan program untuk penciptaan lapangan pekerjaan melalui kegiatan pembangunan secara swakelola dan padat karya tunai; memupuk rasa kebersamaan, gotong royong dan partisipasi masyarakat desa; menekan jumlah pengangguran; serta membangkitkan kegiatan sosial dan ekonomi di desa. Pelaksanaan Program Padat Karya Tunai di Desa Tasikmadu berupa pengembangan kawasan agropolitan. Desa Tasikmadu sebagai sentra produsen buah belimbing madu dalam kawasan agropolitan yang dikelola secara swakelola oleh masyarakat dengan luas mencapai $80 \mathrm{Ha}$. Kegiatan program fokus pada pengembangan kawasan agropolitan kebun belimbing, terdiri atas kegiatan perbaikan sarana prasarana, peningkatan kepariwisataan, pemeliharaan tanaman dan pengadaan sentra kuliner.

\section{Faktor Internal dan Faktor Eksternal Partisipasi}

Faktor internal yaitu faktor yang terdapat di dalam diri individu seperti umur, tingkat pendidikan, luas kepemilikan lahan, tingkat pendapatan dan lamanya tinggal. Umur responden didominasi kategori umur 36-45 tahun (31,88 persen) dan 46-55 tahun (31,88 persen). Umur tersebut termasuk dalam angkatan kerja, yang merupakan tenaga kerja profesional dengan fisik/tenaga yang kuat dan memiliki banyak pengalaman. Berdasarkan tingkat pendidikan responden mayoritas tamat SLTA/Sederajat(50,72 persen).Data menunjukkan bahwa capaian tingkat pendidikan tamat SLTA/ Sederajat lebih banyak dibandingkan tingkat pendidikan yang lain. Artinya masyarakat sudah cukup sadar akan arti pentingnya pendidikan terutama pendidikan formal.

Sejumlah 39 orang $(56,52$ persen $)$ memiliki luas lahan kurang dari 0,3 Ha. Darwis (2009) menyatakan bahwa sebagian besar pendapatan rumah tangga pedesaan umumnya berasal dari kegiatan usaha tani yang membutuhkan lahan sebagai faktor produksi utama. Responden yang memiliki lahan umumnya memanfaatkan lahan untuk usaha tani budidaya tanaman belimbing. Lahan tersebut diolah sendiri atau disewakan kepada orang lain. Tingkat pendapatan responden pada sektor usaha tani diketahui lebih dari 2,1 juta (71,01 persen), pada sektor non usaha tani diketahui kurang dari 500 ribu rupiah (42,03 persen). Pendapatan menurut Mumu (2015) adalah semua penerimaan baik tunai maupun bukan tunai yang merupakan hasil penjualan barang atau jasa dalam kurun waktu tertentu. Sebagian besar responden tinggal di Desa Tasikmadu lebih dari 21 tahun (75,36 persen). Kelompok ini sebagian besar merupakan penduduk asli yang lahir dan bertumbuh di Desa Tasikmadu.

Faktor eksternal yaitu faktor dari luar diri individu, seperti tingkat kekosmopolitan dan stakeholder. Secara keseluruhan tingkat kekosmopolitan responden tergolong dalam kategori sangat rendah (65,21 persen). Hasilnya tercermin pada kurang terbukanya responden terhadap informasi terkait program. Umumnya orang yang sering mengakses informasi dan bepergian keluar wilayah cenderung kosmolit 
atau berpandangan luas, begitu juga sebaliknya, hal ini juga dapat mencerminkan keterbukaan masyarakat dalam menerima informasi guna meningkatkan pengetahuan. Faktor stakeholder berada pada kategori cukup aktif (46,38 persen). Kunjungan cukup sering dilakukan untuk mengawasi keberjalanan Program Padat Karya
Tunai. Pendampingan cukup sering dilakukan untuk memberikan arahan dan evaluasi terhadap keberjalanan kegiatan. Stakeholder pada penelitian ini adalah Kepala Desa dan Ketua Kelompok Masyarakat.

\section{Tingkat Partisipasi Masyarakat dalam Program Padat Karya Tunai}

Tabel 1. Tingkat Partisipasi Masyarakat dalam Pengembangan Kawasan Agropolitan Program Padat Karya Tunai

\begin{tabular}{|c|c|c|c|}
\hline \multirow{2}{*}{ Indikator } & \multirow{2}{*}{ Skor } & \multicolumn{2}{|c|}{ Distribusi } \\
\hline & & (Orang) & (Persen) \\
\hline \multicolumn{4}{|c|}{$\begin{array}{l}\text { Tingkat Partisipasi pada Tahap Perencanaan dan } \\
\text { Pengambilan Keputusan }\end{array}$} \\
\hline Tinggi & $20,32-27,00$ & 25 & 36,23 \\
\hline Sedang & $13,63-20,31$ & 40 & $\mathbf{5 7 , 9 7}$ \\
\hline Rendah & $6,94-13,62$ & 4 & 5,80 \\
\hline Jumlah & & 69 & 100,00 \\
\hline \multicolumn{4}{|c|}{ Tingkat Partisipasi pada Tahap Pelaksanaan } \\
\hline Tinggi & $34,97-45,00$ & 3 & 4,35 \\
\hline Sedang & $24,93-34,96$ & 32 & 46,38 \\
\hline Rendah & $14,89-24,92$ & 34 & 49,27 \\
\hline Jumlah & & 69 & 100,00 \\
\hline \multicolumn{4}{|c|}{ Tingkat Partisipasi pada Tahap Monitoring dan Evaluasi } \\
\hline Tinggi & $37,70-48,00$ & 12 & 17,40 \\
\hline Sedang & $25,90-37,60$ & 52 & 75,36 \\
\hline Rendah & $15,10-25,80$ & 5 & 7,24 \\
\hline Jumlah & & 69 & 100,00 \\
\hline \multicolumn{4}{|c|}{$\begin{array}{l}\text { Tingkat Partisipasi pada Tahap Pemanfaatan dan } \\
\text { Menikmati Hasil }\end{array}$} \\
\hline Tinggi & $27,99-36,00$ & 20 & 28,99 \\
\hline Sedang & $19,97-27,98$ & 42 & 60,87 \\
\hline Rendah & $11,95-19,96$ & 7 & 10,14 \\
\hline Jumlah & & 69 & 100,00 \\
\hline
\end{tabular}

Sumber: Analisis Data Primer (2019)

Tingkat partisipasi masyarakat dalam tahap perencanaan dan pengambilan keputusan adalah sedang $(57,97$ persen). Tingkat partisipasi yang tergolong sedang disebabkan karena masyarakat hanya dilibatkan dalam perencanaan kegiatan pemeliharaan tanaman dan peningkatan kepariwisataan, sedangkan kegiatan perbaikan sarana prasarana serta pengadaan sentra kuliner sudah dirumuskan oleh pemerintah
Desa Tasikmadu. Masyarakat memiliki tingkat partisipasi rendah dalam tahap pelaksanaan (63,77 persen). Partisipasi pada tahap pelaksanaan meliputi sumbangan dana, sumbangan tenaga kerja, dan keikutsertaan selama program. Tahap pelaksanaan ini diukur dari keikutsertaan responden dalam mengikuti pelaksanaan program melalui kegiatan perbaikan sarana prasarana, kegiatan pemeliharaan tanaman, kegiatan peningkatan 
kepariwisataan, dan kegiatan pengadaan sentra kuliner. Masyarakat hanya mengikuti beberapa kegiatan sesuai dengan minat dan kebutuhannya.

Tingkat partisipasi masyarakat pada tahap monitoring dan evaluasi adalah sedang $(75,36$ persen). Hal tersebut dilihat dari keterlibatan responden dalam pengawasan jalannya kegiatan. Masyarakat cukup aktif mengawasi maupun mengevaluasi pelaksanaan kegiatan perbaikan sarana prasarana, pemeliharaan tanaman dan peningkatan kepariwisataan namun pada kegiatan pengadaan sentra kuliner, masyarakat tidak aktif mengawasinya. Keterlibatan tahap monitoring dan evaluasi terdiri atas keterlibatan dalam pengawasan jalannya kegiatan, penilaian kesesuaian rencana dengan pelaksanaan kegiatan, partisipasi dalam memberikan kritik dan saran, serta kepuasan terhadap hasil kegiatan yang dilaksanakan. Masyarakat memiliki tingkat partisipasi sedang pada tahap pemanfaatan dan menikmati hasil (60,87 persen). Tercermin pada peran masyarakat yang terlibat cukup aktif dalam pemanfaatan hasil kegiatan. Sisi lainnya masyarakat tidak aktif terlibat pada kegiatan pelayanan kepariwisataan dan menjalankan usaha kuliner. Penyebabnya adalah terkendala kesibukan dan rutinitas pekerjaan yang beragam. Kegiatan perbaikan sarana prasarana, pemeliharaan tanaman dan peningkatan kepariwisataan dinilai cukup bermanfaat oleh responden karena memberikan dampak positif bagi masyarakat, khususnya kegiatan pemeliharaan tanaman. Kegiatan pemeliharaan tanaman dapat meningkatkan penghasilan. Kegiatan perbaikan sarana prasarana cukup menguntungkan dengan efisiensi dalam mobilitas dan kegiatan peningkatan kepariwisataan dapat membuka lapangan pekerjaan baru. Sedangkan kegiatan pengadaan sentra kuliner oleh responden belum dirasa memberikan manfaat ekonomi, karena masih banyak responden yang belumberkesempatan untuk bergabung pada sentra kuliner tersebut.

Wihandoko (2015) menjelaskan bahwa tingkat partisipasi masyarakat diukur dengan metode kuantitatif melalui penjumlahan skor dari variabel. Besarnya interval skor untuk menentukan kategori tingkat partisipasi didasarkan pada skor kategori tingkat partisipasi individu dengan jumlah sampel. Berdasarkan perhitungan yang telah dilakukan, diketahui total perolehan skor partisipasi adalah 7.036. Tingkat partisipasi tergolong sedang dan derajat partisipasi Arnstein terletak pada tangga keempat yaitu konsultasi (consultation). Tahap konsultasi merupakan komunikasi yang terjadi dua arah. Hakekat kesertaan pada level konsultasi adalah suara aspirasi masyarakat didengar tetapi tidak selalu dipakai sarannya oleh stakeholderterkait.

\section{Hubungan Faktor Internal dan Faktor Eksternal dengan Tingkat Partisipasi Masyarakat dalam Pengembangan Kawasan Agropolitan Program Padat Karya Tunai}

Tabel 2. Signifikansi Hubungan Faktor Internal dan Faktor Eksternal dengan Tingkat Partisipasi Masyarakat

\begin{tabular}{|c|c|c|c|c|c|c|c|c|c|c|}
\hline \multirow{3}{*}{$\begin{array}{c}\text { Faktor Internal dan } \\
\text { Faktor Eksternal } \\
\text { Partisipasi }\end{array}$} & \multicolumn{10}{|c|}{ Tingkat Partisipasi Masyarakat } \\
\hline & \multicolumn{2}{|c|}{ Y1.1 } & \multicolumn{2}{|c|}{ Y1.2 } & \multicolumn{2}{|c|}{ Y1.3 } & \multicolumn{2}{|c|}{ Y1.4 } & \multicolumn{2}{|c|}{ Y Total } \\
\hline & $\mathbf{r}_{\mathrm{s}}$ & $\mathbf{t}_{\text {hitung }}$ & $\mathbf{r}_{\mathrm{s}}$ & $\mathbf{t}_{\text {hitung }}$ & $\mathbf{r}_{\mathrm{s}}$ & $\mathbf{t}_{\text {hitung }}$ & $\mathbf{r}_{\mathrm{s}}$ & $\mathbf{t}_{\text {hitung }}$ & $\mathbf{r}_{\mathrm{s}}$ & $\mathbf{t}_{\text {hitung }}$ \\
\hline Umur (X1) & 0,136 & $-0,123$ & $-0,091$ & $-0,748$ & $-0,076$ & $-0,624$ & $-0,036$ & $-0,295$ & $-0,015$ & $-0,123$ \\
\hline Tingkat Pendidikan (X2) & $0,238^{*}$ & 2,006 & 0,159 & 1,318 & 0,149 & 1,233 & 0,147 & 1,216 & 0,227 & 1,908 \\
\hline $\begin{array}{l}\text { Luas Kepemilikan Lahan } \\
\text { (X3) }\end{array}$ & $0,461 * *$ & 4,254 & $0,404 * *$ & 3,615 & $0,271 *$ & 2,304 & $0,381 * *$ & 3,373 & $0,424 * *$ & 3,828 \\
\hline Tingkat Pendapatan (X4) & $0,405 * *$ & 3,626 & 0,168 & 1,395 & 0,236 & 1,988 & 0,217 & 1,819 & $0,286^{*}$ & 2,443 \\
\hline Lamanya Tinggal (X5) & 0,196 & 1,636 & 0,149 & 1,233 & 0,179 & 1,489 & 0,129 & 1,065 & 0,172 & 1,429 \\
\hline $\begin{array}{l}\text { Tingkat Kekosmopolitan } \\
\text { (X6) }\end{array}$ & $0,570 * *$ & 5,678 & $0,480 * *$ & 4,479 & $0,394 * *$ & 3,509 & $0,457 * *$ & 4,205 & $0,550^{* *}$ & 5,390 \\
\hline Stakeholder (X7) & $0,300^{*}$ & 2,574 & 0,111 & 0,914 & 0,162 & 1,344 & 0,118 & 0,973 & 0,232 & 1,952 \\
\hline
\end{tabular}

Sumber: Analisis Data Primer 2019 
Keterangan :

*) $\quad$ : Signifikan $\left(t_{\text {hitung }}>t_{\text {tabel }}\right)$

**) : Sangat signifikan

Y1.1 : Partisipasi masyarakat tahap perencanaan dan pengambilan keputusan

Y1.2 : Partisipasi masyarakat tahap pelaksanaan

Y1.3 : Partisipasi masyarakat tahap monitoring dan evaluasi

Y1.4 : Partisipasi masyarakat tahap pemanfaatan dan menikmati hasil

Y T : Partisipasi masyarakat dalam Program Padat Karya Tunai

$t_{\text {tabel }} \quad: 1,994$

Hubungan Antara Umur dengan Tingkat Partisipasi Masyarakat

Berdasarkan Tabel 9. diketahui bahwa nilai $r_{s}$ yaitu sebesar $-0,015$ pada $\alpha=0,05$ dengan nilai $t_{\text {hitung }}$ sebesar $-0,123$ dan $t_{\text {tabel }}$ sebesar 1,994 sehingga dapat dilihat bahwa $t_{\text {hitung }}(-0,123)$ $<t_{\text {tabel }}(1,994)$ maka Ho diterima. Artinya tidak terdapat hubungan yang signifikan antara umur dengan tingkat partisipasi masyarakat pada semua tahapan partisipasi dalam pengembangan kawasan agropolitan Program Padat Karya Tunai, karena perbedaan umur pada responden tidak menghalangi responden untuk mengikuti keberjalanan program. Responden yang berumur tua maupun muda memiliki kesempatan yang sama, karena asas dari program ini adalah "dari, oleh dan untuk masyarakat" yang sesuai dengan prinsipnya yaitu partisipatif dan gotong royong.

Hubungan Antara Tingkat Pendidikan dengan Tingkat Partisipasi Masyarakat

Berdasarkan Tabel 9. dapat diketahui bahwa nilai $r_{s}$ sebesar 0,227 pada $\alpha=0,05$ dengan $t_{\text {hitung }}$ sebesar 1,908 dan $t_{\text {tabel }}$ sebesar 1,994 sehingga dapat dilihat bahwa $t_{\text {hitung }}(1,908)<t_{\text {tabel }}(1,994)$ maka Ho diterima. Artinya tidak terdapat hubungan yang signifikan antara tingkat pendidikan dengan tingkat partisipasi masyarakat dalam pengembangan kawasan agropolitan Program Padat Karya Tunai.
Hubungan antara tingkat pendidikan dengan partisipasi masyarakat tahap perencanaan dan pengambilan keputusan menujukkan hasil yang signifikan. Pendidikan pada tahap perencanaan menunjukkan perbandingan lurus, artinya semakin tinggi pendidikan responden menunjukkan bahwa ilmu pengetahuan dan wawasan yang didapat semakin luas, sehingga responden akan lebih mudah dalam menyusun rencana kegiatan. Seperti halnya yang diungkapkan oleh Tjokroamidjojo (1995) bahwa pendidikan menjadi salah satu elemen yang menjadi perhatian partisipasi pembangunan. Tingkat pendidikan memudahkan pemahaman dan menimbulkan kesadaran tinggi bagi masyarakat.

Hubungan Antara Luas Kepemilikan Lahan dengan Tingkat Partisipasi Masyarakat

Berdasarkan Tabel 9. menunjukkan nilai $r_{s}$ yaitu 0,424 pada $\alpha=0,05$ dengan nilai $t_{\text {hitung }}$ sebesar 3,828 dan $t_{\text {tabel }}$ sebesar 1,994 sehingga dapat dilihat bahwa $t_{\text {hitung }}(3,828)>t_{\text {tabel }}(1,994)$ maka Ho ditolak. Artinya terdapat hubungan yang signifikan antara luas kepemilikan lahan dengan tingkat partisipasi masyarakat dalam pengembangan kawasan agropolitan Program Padat Karya Tunai. Darwis (2009) menyatakan bahwa bagi masyarakat desa luas kepemilikan lahan mencerminkan tingkat kesejahteraan karena akan menentukan besarnya pendapatan rumah tangga. Begitu pentingnya peranan lahan dalam kehidupan rumah tangga perdesaan sehingga luas pemilikan lahan seringkali diartikan identik dengan status sosial rumah tangga.

Hubungan Antara Tingkat Pendapatan dengan Tingkat Partisipasi Masyarakat

Tabel 9. menjelaskan besarnya nilai $r_{s}$ yaitu sebesar 0,286 pada $\alpha=0,05$ dengan nilai $t_{\text {hitung }}$ sebesar 2,443 dan $t_{\text {tabel }}$ sebesar 1,994 sehingga dapat dilihat bahwa $t_{\text {hitung }}(2,443)>t_{\text {tabel }}(1,994)$ maka Ho ditolak. Artinya terdapat hubungan yang signifikan antara tingkat pendapatan dengan tingkat partisipasi masyarakat dalam pengembangan kawasan agropolitan Program Padat Karya Tunai. Semakin tinggi tingkat pendapatan maka semakin tinggi pula tingkat partisipasi masyarakat dalam mengikuti program. Seperti yang diungkapkan Mardikanto (1994), tingkat kemampuan ekonomi seseorang 
yang secara ekonomi mampu atau berpendapatan tinggi akan lebih mudah menyediakan modal untuk berpartisipasi. Masyarakat yang memiliki pendapatan sedang atau rendah cenderung mempergunakan waktu yang dimilikinya untuk mendapatkan penghasilan tambahan dibandingkan ikut serta dalam kegiatan program.

Hubungan Antara Lamanya Tinggal dengan Tingkat Partisipasi Masyarakat

Nilai $r$ yaitu sebesar 0,172 pada $\alpha=0,05$ dengan $t_{\text {hitung }}$ sebesar 1,429 dan $t_{\text {tabel }}$ sebesar 1,994 sehingga dapat dilihat bahwa $t_{\text {hitung }}(1,429)<t_{\text {tabel }}$ $(1,994)$ maka Ho diterima. Artinya tidak terdapat hubungan yang signifikan antara lamanya tinggal dengan tingkat partisipasi masyarakat dalam pengembangan kawasan agropolitan Program Padat Karya Tunai. Lamanya tinggal tidak menjadi faktor partisipasi masyarakat dalam mengikuti kegiatan program, karena masyarakat yang sudah tinggal lama maupun masyarakat baru memiliki kesempatan yang sama untuk berpartisipasi. Wijaksono (2013) mengungkapkan bahwa lamanya tinggal biasanya dilihat dari kemampuan komunikasi, baik dalam menerima maupun menyampaikan informasi.

Hubungan Antara Tingkat Kekosmopolitan dengan Partisipasi Masyarakat

Rincian Tabel 9. menunjukkan nilai $r_{s}$ yaitu sebesar 0,550 pada $\alpha=0,05$ dengan nilai $t_{\text {hitung }}$ sebesar 5,390 dan $t_{\text {tabel }}$ sebesar 1,994 sehingga dapat dilihat bahwa $t_{\text {hitung }}(5,390)>t_{\text {tabel }}(1,994)$ maka Ho ditolak. Artinya terdapat hubungan yang sangat signifikan antara tingkat kekospompolitan dengan tingkat partisipasi masyarakat dalam pengembangan kawasan agropolitan Program Padat Karya Tunai. Arah hubungan bernilai positif dan bersifat sedang, sehingga semakin tinggi tingkat kekosmopolitan maka semakin tinggi pula tingkat partisipasi masyarakat dalam mengikuti kegiatan pengembangan kawasan agropolitan Program Padat Karya Tunai. Selaras dengan Azwar et. al., (2016) bahwa responden yang memiliki tingkat kekosmopolitan tinggi lebih banyak menerima informasi dari berbagai sumber informasi akibat adanya interaksi dengan orangorang luar.
Hubungan Antara Stakeholder dengan Tingkat Partisipasi Masyarakat

Tabel 9. menunjukkan nilai $r_{s}$ yaitu sebesar 0,232 pada $\alpha=0,05$ dengan nilai $t_{\text {hitung }}$ sebesar 1,952 dan nilai $t_{\text {tabel }}$ sebesar 1,994 sehingga dapat dilihat bahwa $t_{\text {hitung }}(1,952)<t_{\text {tabel }}(1,994)$ maka Ho diterima. Artinya tidak terdapat hubungan yang signifikan antara stakeholder dengan tingkat partisipasi masyarakat dalam pengembangan kawasan agropolitan Program Padat Karya Tunai. Indikator stakeholder tidak memberikan hubungan yang signifikan karena keberadaan pemangku kebijakan termasuk kepala desa dan ketua kelompok masyarakat tidak menghalangi dan tidak meningkatkan partisipasi masyarakat pada keberlangsungan kegiatan program.

\section{KESIMPULAN DAN SARAN}

\section{Kesimpulan}

Faktor internal dan faktor eksternal yang mempengaruhi partisipasi masyarakat dalam pengembangan kawasan agropolitan Program Padat Karya Tunai di Desa Tasikmadu Kecamatan Palang Kabupaten Tuban, yaitu: umur responden berkisar antara 36-45 tahun dan 46-55 tahun $(31,88 \%)$, tingkat pendidikan responden adalah tamat SLTA/Sederajat(50,72\%), luas kepemilikan lahan responden adalah $\leq 0,3 \mathrm{Ha}$ $(56,52 \%)$, tingkat pendapatan responden pada sektor usaha tani adalah lebih dari Rp 2.100.000,00 (71,01\%) sedangkan tingkat pendapatan dari sektor non usaha tani adalah kurang dari Rp 500.000,00 (42,03\%), lamanya tinggal responden yaitu> 21 tahun $(75,36 \%)$, tingkat kekosmopolitan responden dalam kategori sangat rendah $(65,20 \%)$, dan stakeholder termasuk dalam kategori cukup aktif (46,38\%).Tingkat partisipasi masyarakat dalam pengembangan kawasan agropolitan Program Padat Karya Tunai pada tahap perencanaan dan pengambilan keputusan tergolong dalam kategori sedang $(57,97 \%)$, pada tahap pelaksanaan dalam kategori rendah $(49,27 \%)$, pada tahap monitoring dan evaluasi 
tergolong dalam kategori sedang (75,36\%), dan pada tahap pemanfaatan serta menikmati hasil tergolong kategori sedang (60,87\%). Tingkat partisipasi masyarakat secara keseluruhan termasuk kategori partisipasi sedang, dan derajat partisipasinya berada pada tangga konsultasi.Terdapat hubungan yang signifikan antara faktor luas kepemilikan lahan, tingkat pendapatan dan tingkat kekosmopolitan dengan tingkat partisipasi masyarakat. Sedangkan faktor umur, tingkat pendidikan, lamanya tinggal dan stakeholder dengan tingkat partisipasi masyarakat tidak memiliki hubungan yang signifikan.

\section{Saran}

Kelompok Masyarakat diharapkan dapat meningkatkan peran kelembagaan sebagai wadah akses informasi Program Padat Karya Tunai dengan cara meningkatkan intensitas diskusi, rapat dan sosialisasi.Masyarakat beserta stakeholder perlu meninjau kembali rencana (master plan) pengembangan kawasan agropolitan guna mengevaluasi dan memperbaiki kekurangan dalam pelaksanaan program dengan menggali potensi sumber daya yang ada.Ketua Kelompok Masyarakat harus lebih aktif mendorong dan mengarahkan masyarakat agar berperan aktif dalam Program Padat Karya Tunai yang memiliki banyak keuntungan, salah satunya adalah peningkatan pendapatan

\section{DAFTAR PUSTAKA}

[BPS] Badan Pusat Statistik. 2017. Kecamatan Palang dalam Angka 2017. www.bps.go.id. Diakses pada 29 September 2018

[Depkes RI] Departemen Kesehatan Republik Indonesia. 2009. Profil Kesehatan Indonesia. Jakarta: Departemen Republik Indonesia

[Kementerian PPN/Bappenas] Kementrian Perencanaan Pembangunan Nasional Republik Indonesia/Badan Perencanaan Pembangunan Nasional. 2018. Pedoman Umum Pelaksanaan Padat Karya Tunai di Desa Tahun 2018
Azwar, Muljono dan Herawati. 2016. Persepsi dan Partisipasi Petani dalam pelaksanaan Rehabilitasi Tanaman Kakao di Kabupaten Sigi Provinsi Sulawesi Tengah. Jurnal penyuluhan 12(2): 157-167

Azzumar, R.M. 2011. Pengaruh Pendapatan Asli Daerah, Investasi Swasta dan Tenaga Kerja terhadap Pertumbuhan Ekonomi. Semarang: Universitas Diponegoro

Darwis, V. 2009. Petani, Penentu Pendapatan. Keragaan Penguasaan Lahan Sebagai Faktor Utama. Jurnal Agro Ekonomi www.e-journal.litbang.pertanian.go.id

Mardikanto, T. 1994. Bunga Rampai Pembangunan Pertanian. Surakarta: UNS Press

Mumu, A.R. 2015. Faktor-Faktor yang Mempengaruhi Tingkat Pendapatan Wirausaha Masyarakat di kelurahan Malalayang II. E-Journal Acna Diurna 4(3): $1-5$

Slamet. 1993. Pembangunan Masyarakat Berwawasan Partisipasi. Surakarta: Sebelas Maret University Press

Tjokroamidjojo, B. 1995. Buku Pengantar Administrasi Pembangunan. Jakarta: LP3ES

Wibowo, A. 2016. Partisipasi yang Humanis Sebuah Refleksi Kearifan Lokal Masyarakat Samin di Bawah Terpaan Globalisasi. Surakarta: UNS Press

Wihandoko, A. 2015. Presepsi dan Partisipasi Masyarakat Pada Program Nasional Pemberdayaan Masyarakat Mandiri (PNPM Mandiri) di Kabupaten Mesuji (Studi Kasus Kecamatan Tanjungraya). http://digilib. unila.ac.id/id/eprint/8730. Diakses pada 30 Oktober 2018

Wijaksono, S. 2013. Pengaruh Lama Tinggal Terhadap Tingkat Partisipasi Masyarakat dalamPengelolaan Lingkungan Pemukiman. Jurnal ComTech 4(1): 24-32 